\title{
Polymerase chain reaction-mediated DNA fingerprinting for epidemiological studies on Campylobacter spp.
}

\author{
B. A. J. GIESENDORF* $\dagger$, H. GOOSSENS§, H. G. M. NIESTERS* $\ddagger$ A. VAN BELKUM*, A. KOEKEN*, \\ H. P. ENDTZ $\ddagger$, H. STEGEMAN $\dagger$ and W. G. V. QUINT* ${ }^{*}$ \\ - Diagnostic Centre SSDZ, Department of Molecular Biology, PO Box 5010, 2600 GA Delft, † State Institute for \\ Quality Control of Agricultural Products, Department of Microbiology, PO Box 230, 6700 AE Wageningen, \\ $\ddagger$ University Hospital Rotterdam-Dijkzigt, Department of Clinical Microbiology and Virology, Dr Molewaterplein 40, \\ 3015 GD Rotterdam, The Netherlands and §Laboratory of Clinical Microbiology, University Hospital Antwerp, 2650 \\ Edegem, Belgium
}

\begin{abstract}
Summary. The applicability of polymerase chain reaction (PCR)-mediated DNA typing, with primers complementary to dispersed repetitive DNA sequences and arbitrarily chosen DNA motifs, to study the epidemiology of campylobacter infection was evaluated. With a single PCR reaction and simple gel electrophoresis, strain-specific DNA banding patterns were observed for Campylobacter jejuni and C. upsaliensis. DNA from multiple strains isolated during an outbreak of $C$. jejuni meningitis generated identical banding patterns and could be distinguished from randomly isolated strains. Strains from a community outbreak of $C$. upsaliensis, that were all identical by conventional typing methods, could be divided into two genetically different groups. This report illustrates that PCR fingerprinting can be successfully applied in epidemiological investigations of campylobacter infections.
\end{abstract}

\section{Introduction}

Since campylobacters were recognised as major human pathogens more than two decades ago, there have been significant improvements in bacterial isolation, taxonomy, pathogenesis, epidemiology and molecular biology. ${ }^{1}$ Animals are the main reservoir for strains infecting man. ${ }^{2}$ This emphasises the need for differentiation of isolates to define the possible role that non-human sources play in human infections. The most widely used methods for typing Campylobacter spp. include biotyping, ${ }^{3-5}$ serotyping ${ }^{6,7}$ and phage typing. $^{8-10}$ Although a combination of these three typing methods offers additional discriminatory power, ${ }^{11,12}$ a considerable proportion of strains remain non-typable. Molecular techniques based on the detection of restriction fragment length polymorphisms (RFLP), pulsed-field gel electrophoresis (PFGE) and multilocus enzyme analysis enable subtyping of strains even within serotypes. ${ }^{13}$ However, these techniques are complex and unsuitable for routine application.

Recently, the polymerase chain reaction (PCR) has been used for the genetic typing of isolates of different micro-organisms. ${ }^{14-16}$ Besides the use of short, randomly chosen primers, described in a study of $C$. jejuni epidemiology in poultry broiler flocks, ${ }^{17,18}$ primers directed at repetitive DNA sequences can be of great value for the typing of micro-organisms. ${ }^{16,19-21}$ The presence of repetitive, extragenic palindromic
(REP) elements and enterobacterial repetitive intergenic consensus (ERIC) sequences has been demonstrated for many different bacterial species. ${ }^{21}$ Multiple functions have been proposed for these highly conserved, dispersed elements, including roles in transcription termination, mRNA stability and chromosomal domain organisation in vivo. ${ }^{21}$ Because no single function satisfactorily explains their DNA sequence conservation or ubiquitous distribution, the suggestion has been made that these elements represent "selfish" DNA sequences which are maintained and propagated through gene conversion. ${ }^{22}$

In this report, the applicability of PCR-mediated DNA typing for various isolates of medically important Campylobacter spp. was investigated with the aid of REP, ERIC and arbitrary DNA motifs. Strains isolated during separate outbreaks of $C$. jejuni and $C$. upsaliensis infections were studied. The results were compared with those obtained from conventional typing methods.

\section{Materials and methods}

\section{Bacterial strains}

$C$. jejuni. The $C$. jejuni reference serotype strains used in this study are listed in table I. A second group of $C$. jejuni strains was isolated during a nosocomial outbreak of $C$. jejuni meningitis between $13 \mathrm{Jan}$. and 24 Feb., 1984 in Laon, France. ${ }^{23}$ These strains are

Received 8 April 1993; accepted 5 Aug. 1993. 
Table I. C. jejuni reference strains used in this study

\begin{tabular}{|c|c|c|c|}
\hline Biotype & Serovar & Strain & Source \\
\hline \multicolumn{4}{|c|}{ I Lior's scheme } \\
\hline C. jejuni I & LIO 1 & 134 & $\operatorname{man}$ \\
\hline C. jejuni II & LIO 2 & 195 & $\operatorname{man}$ \\
\hline C. jejuni I & LIO 4 & 1/NCTC11168 & $\operatorname{man}$ \\
\hline C. jejuni I & LIO 5 & 170 & $\operatorname{man}$ \\
\hline C. jejuni III & LIO 6 & 6 & $\operatorname{man}$ \\
\hline C. jejuni I & LIO 7 & 35 & $\operatorname{man}$ \\
\hline C. jejuni I & LIO 9 & 88 & $\operatorname{man}$ \\
\hline C. jejuni I & LIO 10 & 142 & $\operatorname{man}$ \\
\hline C. jejuni I & LIO 11 & 244 & man \\
\hline C. jejuni II & LIO 16 & 728 & $\operatorname{man}$ \\
\hline C. jejuni I & LIO 17 & 556 & chicken \\
\hline C. jejuni III & LIO 18 & 563 & chicken \\
\hline C. jejuni I & LIO 22 & 918/PC353 & $\operatorname{man}$ \\
\hline C. jejuni II & LIO 23 & 720 & $\operatorname{man}$ \\
\hline C. jejuni I & LIO 28 & 1180 & $\operatorname{man}$ \\
\hline C. jejuni III & LIO 30 & $1215 / A 1616$ & $\operatorname{man}$ \\
\hline C. jejuni I & LIO 32 & 910 MK 192 & $\operatorname{man}$ \\
\hline C. jejuni I & LIO 33 & 1545 & $\operatorname{man}$ \\
\hline C. jejuni III & LIO 38 & $2418 / \mathrm{Y} 438$ & $\operatorname{man}$ \\
\hline C. jejuni I & LIO 39 & 3238/AP14R81 & $\operatorname{man}$ \\
\hline C. jejuni II & LIO 49 & 3235/AP11R81 & $\operatorname{man}$ \\
\hline C. jejuni III & LIO 61 & 5778/AP39849 & $\operatorname{man}$ \\
\hline C. jejuni $I I$ & LIO 62 & $4452 / \mathrm{CO} 1084$ & $\operatorname{man}$ \\
\hline C. jejuni II & LIO 68 & $7219 / \mathrm{BC} 4862$ & $\operatorname{man}$ \\
\hline C. jejuni IV & LIO 74 & $7502 / \mathrm{BC} 4964$ & $\operatorname{man}$ \\
\hline \multicolumn{4}{|c|}{ II Lauwer's scheme } \\
\hline C. jejuni & LAU 1 & A2 & $\operatorname{man}$ \\
\hline C. jejuni & LAU 16 & Bal & Bangladesh \\
\hline \multicolumn{4}{|c|}{ III Penner's scheme } \\
\hline C. jejuni $I I$ & Pen T2 & - & - \\
\hline C. jejuni $I$ & Pen T3 & - & - \\
\hline C. jejuni II & Pen T4 & - & - \\
\hline C. jejuni II & Pen T7 & - & - \\
\hline C. jejuni $I$ & Pen T8 & 一 & - \\
\hline C. jejuni III & Pen T9 & - & - \\
\hline
\end{tabular}

Table II. C. jejuni strains isolated during a nosocomial outbreak of $C$. jejuni meningitis

\begin{tabular}{ccl}
\hline $\begin{array}{c}\text { Baby } \\
\text { no. }\end{array}$ & $\begin{array}{c}\text { Strain } \\
\text { no. }\end{array}$ & Source \\
\hline 1 & 1017 & blood \\
1021 & CSF \\
& 1023 & stool \\
& 1025 & blood \\
2 & 1026 & blood \\
3 & 1027 & stool \\
4 & 1029 & CSF \\
& 1031 & blood \\
5 & 1034 & blood \\
6 & 1035 & blood
\end{tabular}

CSF, cerebrospinal fluid.

listed in table II and were biotyped ${ }^{4}$ and serotyped., 24 Antibiotic susceptibility patterns were determined and plasmid and protein profiles were analysed..$^{25}$

C. upsaliensis. Two groups of strains were included for typing. The first group comprised 54 strains that were isolated during an outbreak of $C$. upsaliensis enteritis in four day-care centres in Brussels in $1991^{26}$ and are listed in table III. A second group consisted of 30 strains (B531, B535, B542, B572, C222, C225, D391, D412, D424, D432, D457, E282, E292, E293,
Table III. C. upsaliensis strains isolated during an outbreak of $C$. upsaliensis enteritis in four day-care centres

\begin{tabular}{|c|c|c|}
\hline $\begin{array}{l}\text { Day-care } \\
\text { centre }\end{array}$ & $\begin{array}{c}\text { Strain } \\
\text { no. }\end{array}$ & $\begin{array}{l}\text { Date of } \\
\text { isolation }\end{array}$ \\
\hline A & 3457 & 180191 \\
\hline A & 3461 & 290191 \\
\hline A & 3463 & 020191 \\
\hline A & 3464 & 040291 \\
\hline A & 3466 & 180291 \\
\hline A & 3473 & 070391 \\
\hline B & 3474 & 050391 \\
\hline $\mathrm{C}$ & 3494 & 280491 \\
\hline $\mathrm{C}$ & 3512 & 210991 \\
\hline C & 3515 & 051091 \\
\hline $\mathrm{C}$ & 3517 & 071091 \\
\hline $\mathrm{C}$ & 3518 & 071091 \\
\hline $\mathrm{C}$ & 3519 & 071091 \\
\hline $\mathrm{C}$ & 3520 & 071091 \\
\hline $\mathrm{C}$ & 3521 & 071091 \\
\hline $\mathrm{C}$ & 3522 & 071091 \\
\hline $\mathrm{C}$ & 3523 & 081091 \\
\hline $\mathrm{C}$ & 3524 & 091091 \\
\hline $\mathrm{C}$ & 3525 & 101091 \\
\hline $\mathrm{C}$ & 3538 & 151091 \\
\hline $\mathrm{C}$ & 3539 & 151091 \\
\hline $\mathrm{C}$ & 3544 & 161091 \\
\hline $\mathrm{C}$ & 3546 & 171091 \\
\hline $\mathrm{C}$ & 3548 & 181091 \\
\hline $\mathrm{C}$ & 3568 & 200192 \\
\hline $\mathrm{C}$ & 3569 & 200192 \\
\hline $\mathrm{C}$ & 3570 & 200192 \\
\hline $\mathrm{C}$ & 3571 & 200192 \\
\hline $\mathrm{C}$ & 3575 & 210192 \\
\hline D & 3513 & 170991 \\
\hline D & 3526 & 101091 \\
\hline D & 3527 & 101091 \\
\hline D & 3528 & 101091 \\
\hline D & 3529 & 101091 \\
\hline D & 3530 & 101091 \\
\hline D & 3531 & 101091 \\
\hline D & 3532 & 101091 \\
\hline D & 3533 & 101091 \\
\hline D & 3535 & 111091 \\
\hline D & 3536 & 111091 \\
\hline D & 3537 & 141091 \\
\hline D & 3541 & 151091 \\
\hline D & 3542 & 151091 \\
\hline D & 3543 & 161091 \\
\hline D & 3545 & 171091 \\
\hline D & 3552 & 241091 \\
\hline D & 3560 & 170192 \\
\hline D & 3561 & 170192 \\
\hline D & 3562 & -0192 \\
\hline D & 3572 & -0192 \\
\hline D & 3573 & 210192 \\
\hline D & 3574 & 210191 \\
\hline D & 3577 & 230191 \\
\hline D & 3578 & 230191 \\
\hline
\end{tabular}

E297, E321, H180, H184, H197, H204, K178, L194, L206, L221, M375, P97, R209, R219, S248, V295) isolated from the stools of patients during a 3-year survey of the prevalence of $C$. upsaliensis at St Pieter's Hospital, Brussels, Belgium. ${ }^{27,28}$ These strains were characterised by several procedures, namely SDSPAGE of whole cell proteins, phenotypic and biochemical characterisation, antibiotic susceptibility testing and plasmid analysis. ${ }^{27}$ All strains (B531-V295) were shown to be different by these typing methods. 


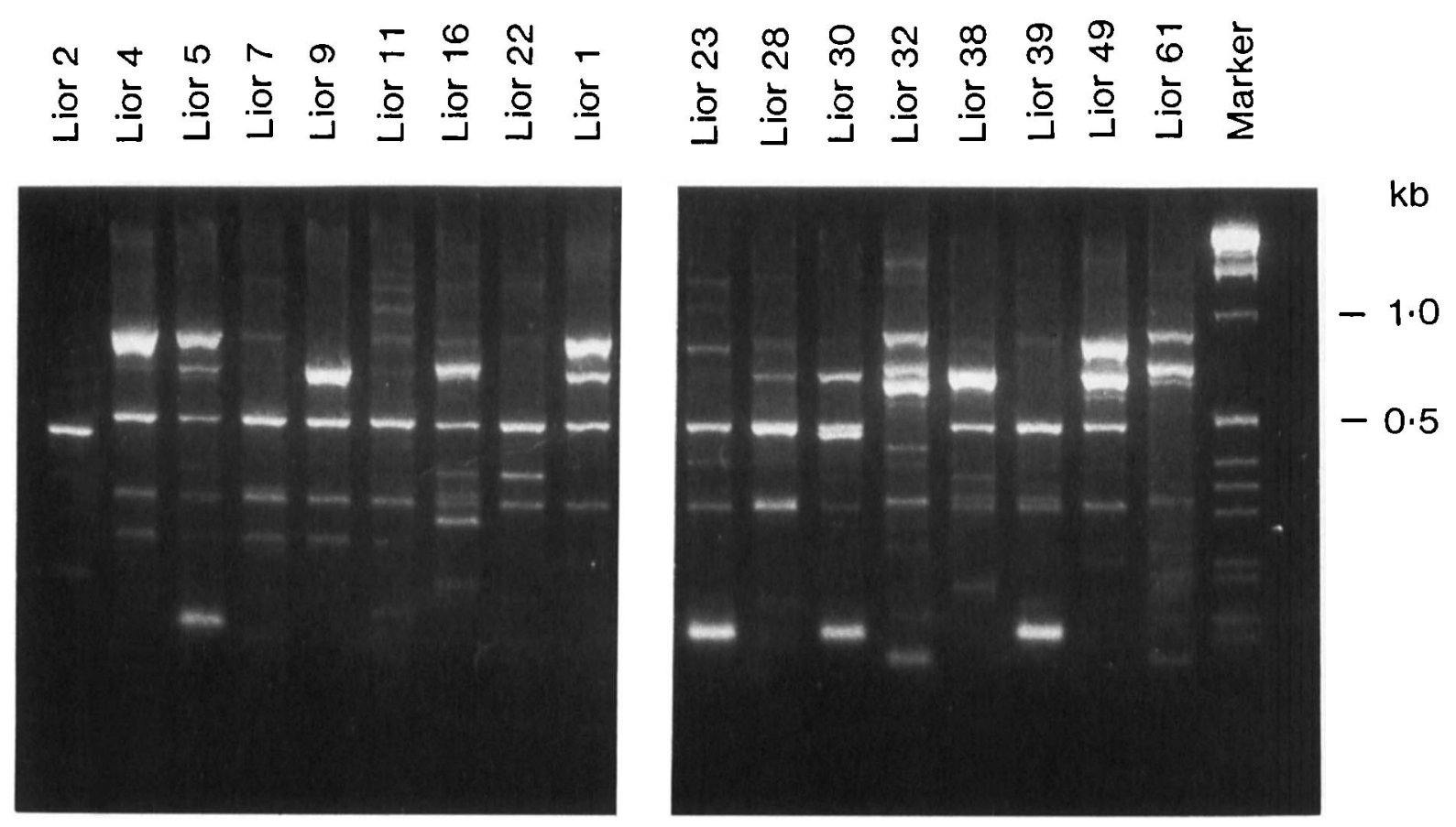

Fig. 1. Comparison of PCR amplification of DNA extracted from a selected number of $C$. jejuni reference serotype strains (Lior serotypes as indicated). The DNA banding patterns shown were generated with a combination of primers ERIC-1R and ERIC-2. Marker, 1-kb DNA ladder.

\section{Extraction of nucleic acids}

Nucleic acids were extracted according to standard procedures. ${ }^{29,30}$ The bacterial pellet $(100 \mu \mathrm{l})$ was suspended in $150 \mu$ l of GET buffer ( $50 \mathrm{~mm}$ glucose, $10 \mathrm{~mm}$ EDTA, $25 \mathrm{~mm}$ Tris-HCl, $\mathrm{pH} 8.0$ ) and incubated for $5 \mathrm{~min}$ at room temperature with $10 \mu \mathrm{l}$ of lysozyme $(125 \mathrm{mg} / \mathrm{ml})$. After the addition of $12.5 \mu \mathrm{l}$ of proteinase $\mathrm{K}(1 \mathrm{mg} / \mathrm{ml})$ and $12.5 \mu \mathrm{l}$ of sodium dodecyl sulphate (SDS) $10 \%$, incubation was continued for $30 \mathrm{~min}$ at $37^{\circ} \mathrm{C}$. Nucleic acids were extracted with phenol, phenol:chloroform:isoamylalcohol $(25: 24$ : 1) and chloroform:isoamylalcohol $(24: 1)$, respectively. Nucleic acids were precipitated by adding $0 \cdot 1$ volume of $3 \mathrm{M}$ sodium acetate, $\mathrm{pH} 5 \cdot 2$, and 2.5 volume of ethanol $96 \%$. After centrifugation, nucleic acid pellets were washed, dried and resuspended in doubledistilled water. The nucleic acid concentration was estimated by ethidium bromide staining of samples run on an agarose $1 \%$ gel with known amounts of phage $\lambda$ DNA as reference.

\section{DNA amplification}

REPIR-1, ERIC-1R and ERIC-2 ${ }^{21}$ and an arbitrary primer 1026: 5'TACATTCGAGGACCCCTAAGT$\mathrm{G}^{\prime}{ }^{16,31}$ were evaluated with respect to their applicability in PCR-mediated genotyping studies. These primers were selected on the basis of the generation of polymorphic DNA banding patterns for different $C$. jejuni and $C$. upsaliensis strains. ${ }^{19,26}$ REP and ERIC primers are homologous to repetitive intergenic sequences and amplify DNA fragments present between inserted copies of these sequences provided that the distance does not exceed $2 \mathrm{~kb}$. Oligonucleotides were prepared on an ABI 386 DNA synthesiser by phosphoramidite technology. Oligonucleotides containing inosine were obtained from Pharmacia, Woerden, The Netherlands. PCR was performed as described previously ${ }^{19}$ and was identical in all experiments. PCR was performed in $100-\mu 1$ volumes containing $10 \mathrm{~mm}$ Tris- $\mathrm{HCl}, \mathrm{pH} 8.3,50 \mathrm{~mm} \mathrm{KCl}, 1.5 \mathrm{~mm}$ $\mathrm{MgCl}_{2}$, gelatin $0.01 \%, 200 \mu \mathrm{M}$ of each desoxynucleotide triphosphate and up to $100 \mathrm{ng}$ of template DNA. Taq DNA polymerase (Sphaero Q, Leiden, The Netherlands) (0.625 unit) was included for each reaction and 35 reaction cycles $\left(1 \mathrm{~min}\right.$ at $94^{\circ} \mathrm{C}, 1 \mathrm{~min}$ at $25^{\circ} \mathrm{C}$ and $4 \mathrm{~min}$ at $74^{\circ} \mathrm{C}$ ) were performed, preceded by an initial 5 min denaturation at $94^{\circ} \mathrm{C}$ and followed by a final elongation step of $10 \mathrm{~min}$ at $74^{\circ} \mathrm{C}$. All PCR reactions were performed in a Biomed thermocycler (type 60). PCR products were separated on agarose $2 \%$ gels and stained with ethidium bromide.

\section{Results}

To investigate the applicability of PCR-mediated DNA typing, isolates collected during an outbreak of C. jejuni meningitis and an outbreak of C. upsaliensis enteritis were studied and compared to a number of reference strains.

To illustrate the polymorphism, fig. 1 shows DNA banding patterns from a selection of the $C$. jejuni 
A

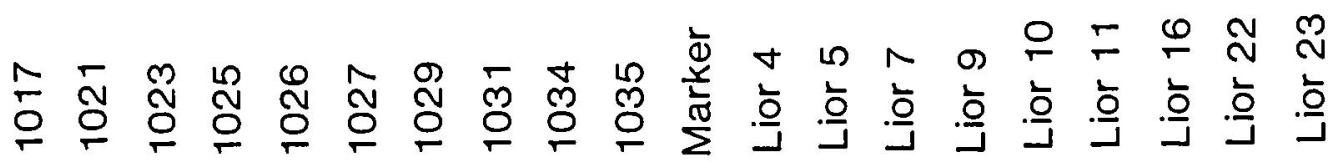

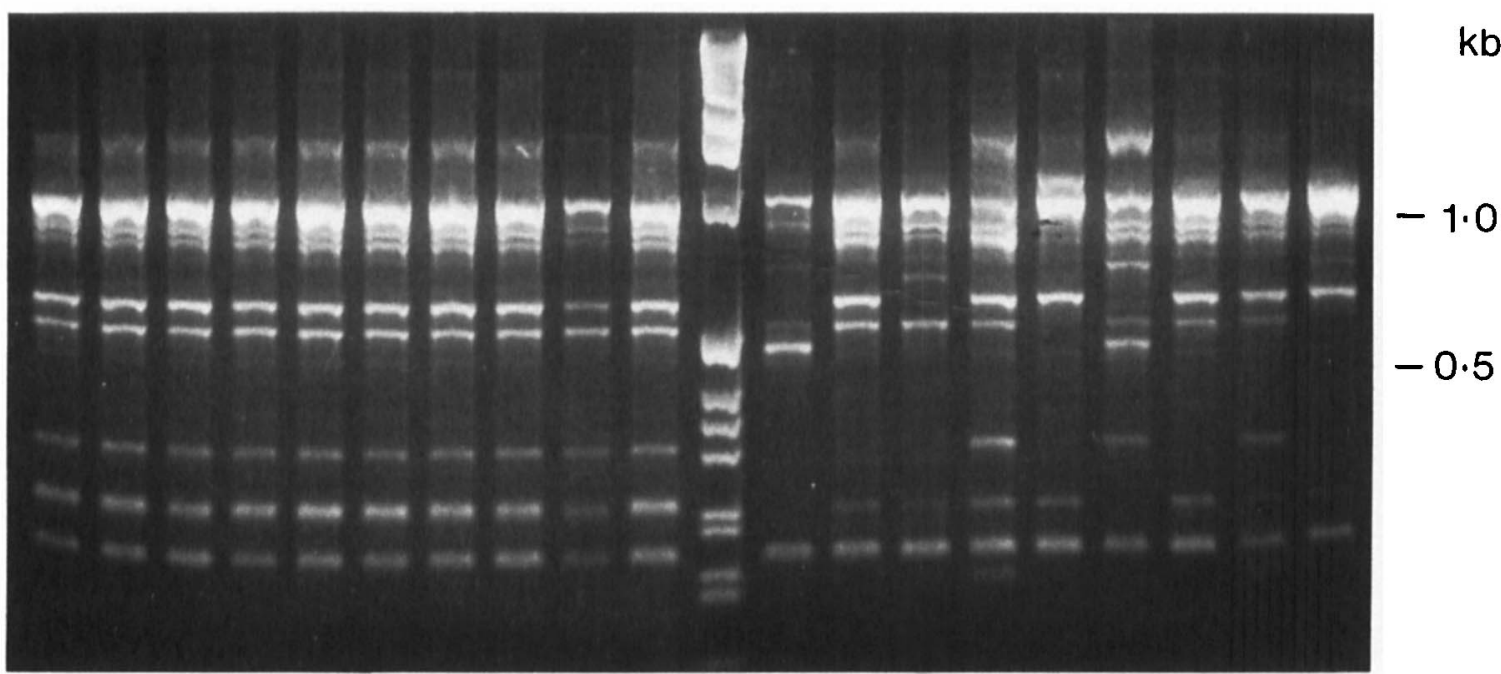

B

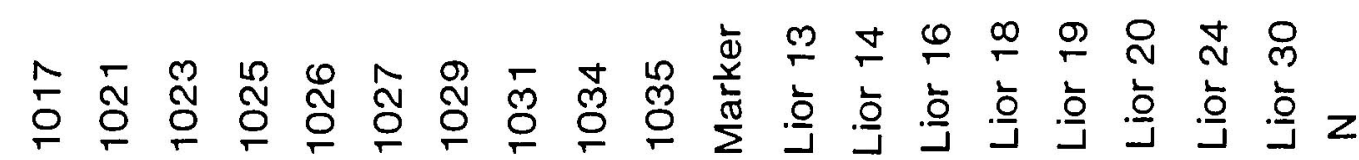

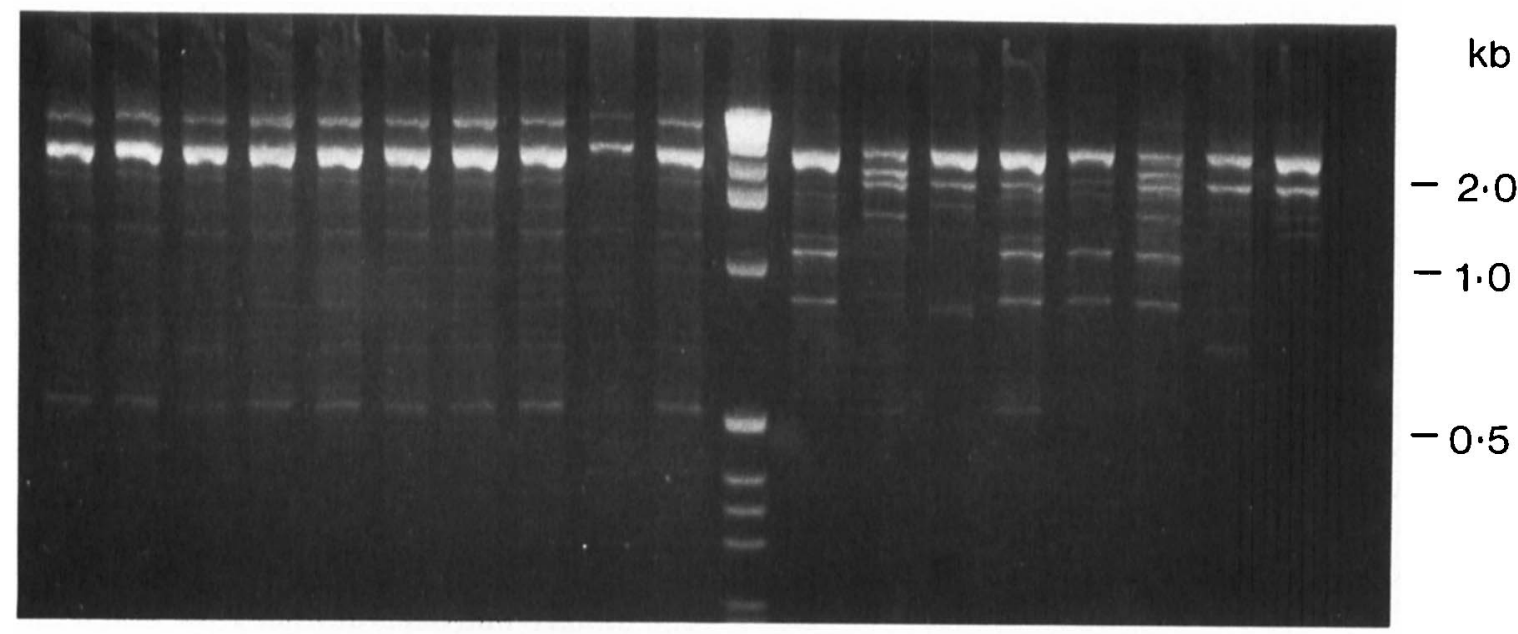

Fig. 2. A, Comparison of PCR amplification of DNA extracted from the $10 C$. jejuni isolates from the meningitis outbreak, lanes $\mathbf{1 0 1 7}-\mathbf{1 0 3 5}$, and a selection of serologically different $C$. jejuni strains (numbers as indicated on top). A combination of primers ERIC-2 and 1026 was used. Marker, 1-kb DNA ladder. B, Results of PCR amplification of DNA extracted from the $10 C$. jejuni isolates from the meningitis outbreak. lanes 1017-1035, and a different set of serologically different $C$. jejuni strains, serotype (numbers as indicated on top), using primer REPIR1. $\mathrm{N}$, negative control; marker, 1-kb DNA ladder.

reference serotype strains. Although a resemblance in patterns can be observed for a number of strains (e.g., Lior 4 and Lior 5), all strains can be distinguished on the basis of the banding patterns generated with the combination of primers ERIC-1R and ERIC-2. In the case of Lior 4 and Lior 5, distinction is determined by the presence of additional fragments present for Lior 5: a 700-, a 350- and a 150-bp fragment. Primer combination ERIC-2 and 1026, and primer REPIR-1 generated similar results (data not shown). With respect to the outbreak of $C$. jejuni meningitis, chromosomal DNA of strains obtained from seven neonates with meningitis was analysed with PCR, and conventional typing was performed.

Figs. 2A and 2B show DNA fingerprints from the strains isolated during the meningitis outbreak, compared with banding patterns obtained from a selection of the 33 reference serotype strains. With primer set 
A

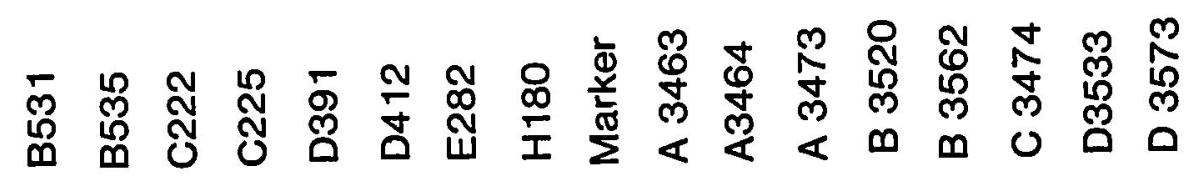

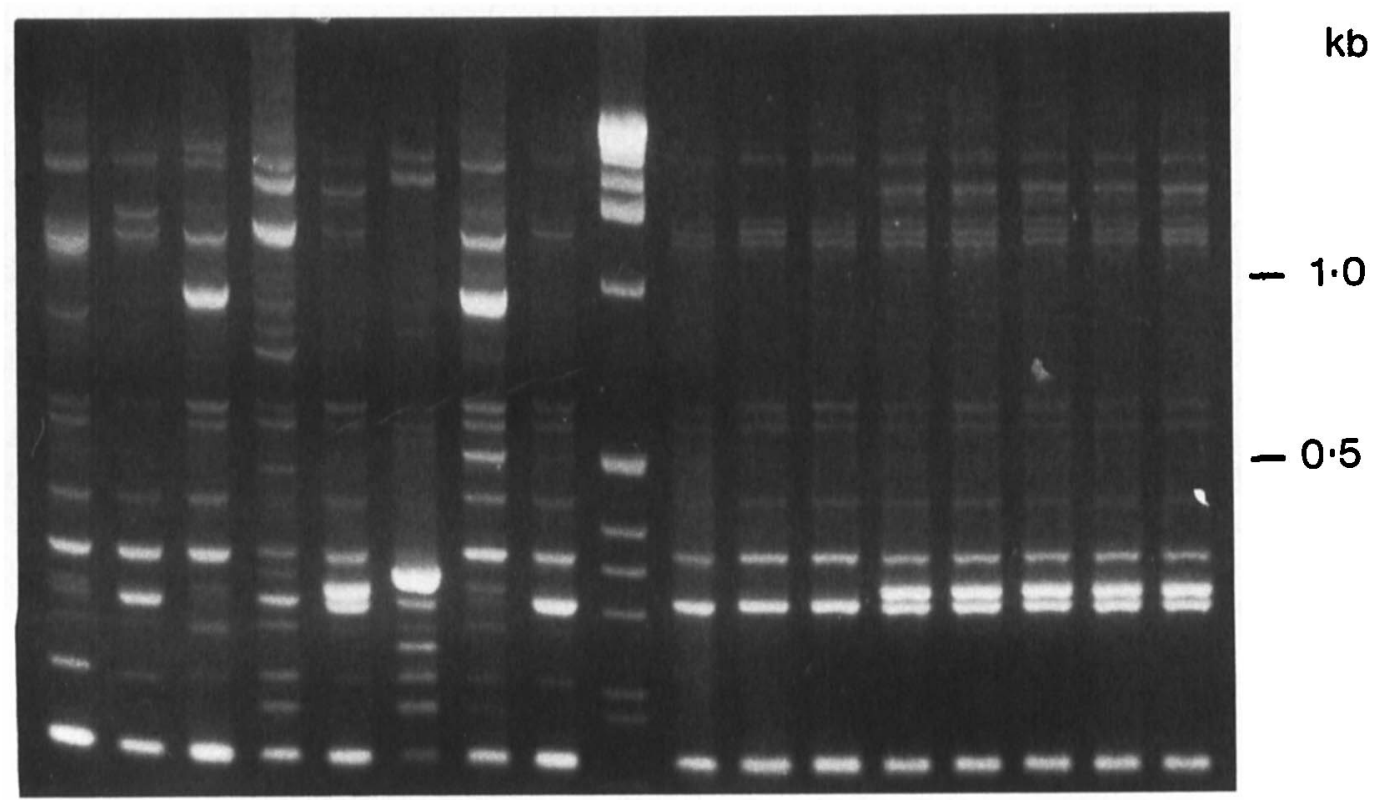

B
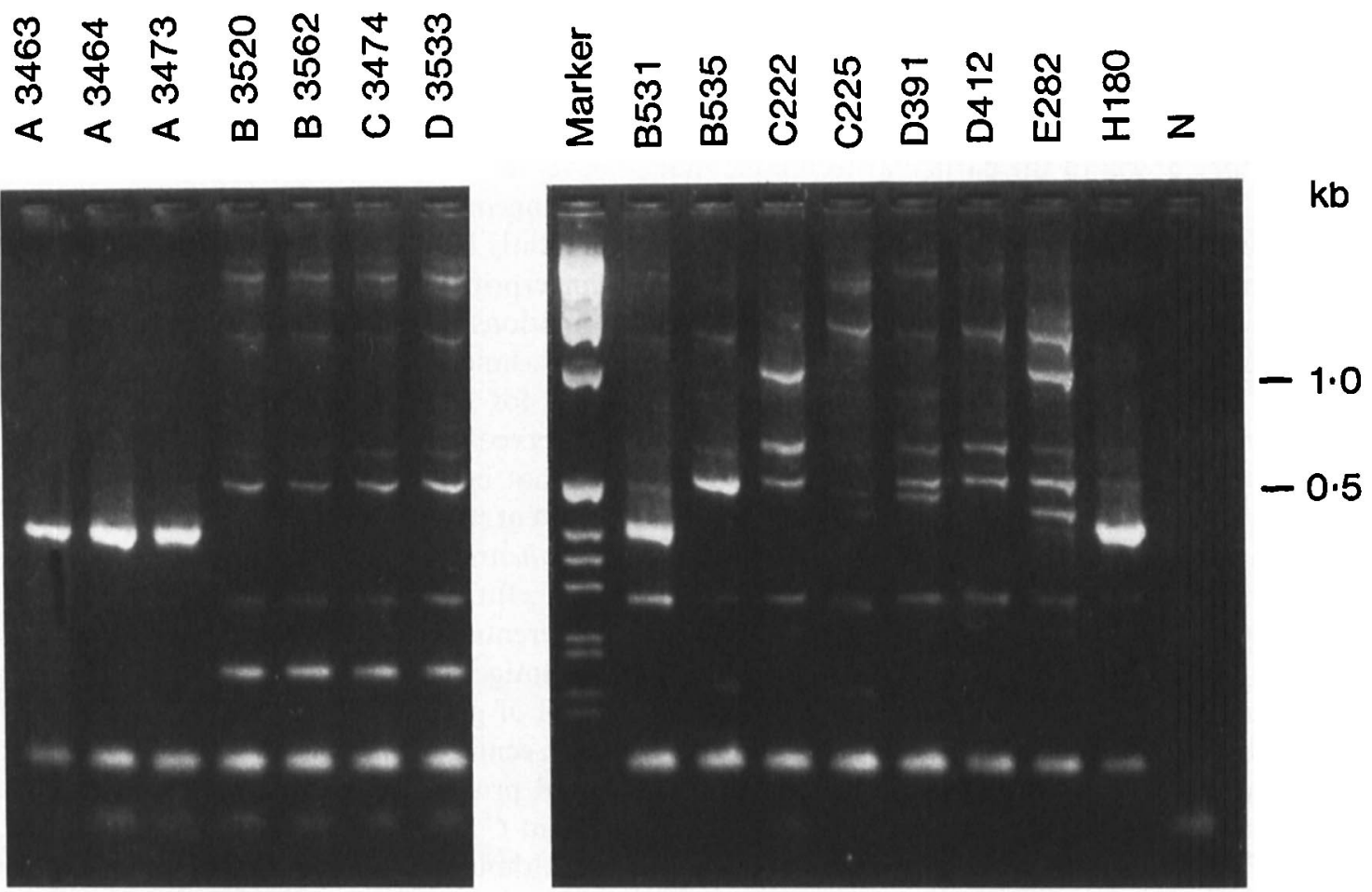

Fig. 3. A, Results of PCR amplification of DNA extracted from a representative selection of strains isolated during the C. upsaliensis outbreak compared to a group of $C$. upsaliensis strains isolated during a 3-year survey, with primers ERIC-1R and ERIC-2. Lanes B531-H180 contain a selected number of $C$. upsaliensis strains isolated from the stools of patients, unrelated to the outbreak. Lanes A3463-D3573 contain strains isolated at day-care centre A, B, C or D as indicated. Marker, 1-kb DNA ladder; N, negative control. B, Comparison of PCR amplification of DNA extracted from the C. upsaliensis outbreak strains, lanes A34631-D3533, compared to C. upsaliensis strains isolated during a 3-year survey, lanes B531-H180 as indicated. N, negative control; marker, 1-kb DNA ladder.

ERIC-2 and 1026 (fig. 2A), DNA products of sizes ranging from $c .2000 \mathrm{bp}$ to $150 \mathrm{bp}$ were generated. All outbreak-related strains had identical DNA banding patterns and could be discriminated from the nonoutbreak strains. Similar results were obtained with primer REPIR-1, as can be seen in fig. 2B. Outbreak 
strain 1034 showed a less intense banding pattern which was, however, identical to the patterns from the other outbreak strains. This was confirmed by repeated testing. Primers ERIC-1R and ERIC-2 also generated identical banding patterns for all outbreak-related strains, and discriminated these from non-outbreak strains (data not shown).

PCR-mediated DNA typing was also used to study a community outbreak of $C$. upsaliensis enteritis in four day-care centres. Chromosomal DNA of 54 outbreak isolates was compared by PCR analysis with DNA of 30 non-outbreak strains of $C$. upsaliensis. With primer combinations ERIC-1R and ERIC-2, and ERIC-2 and 1026, outbreak strains could be divided into two groups. Figs. 3A and 3B show that the banding patterns obtained from the strains isolated at day-care centre A were identical, but different from the DNA patterns obtained from strains isolated from children of day-care centres B, C and D. DNA fingerprints from the latter group (B, C and D) were identical. Furthermore, C. upsaliensis outbreakrelated strains (from all four day-care centres) could be clearly discriminated from all 30 non-outbreak strains by PCR. A selected number is shown in figs. 3A and B (B531-H180). Primer REPIR-1 could not be used successfully for PCR fingerprinting of $C$. upsaliensis (data not shown).

\section{Discussion}

The value of any typing procedure depends on the discriminatory power of the particular technique that is applied. This depends in turn on the characteristics being measured. Combining several typing schemes such as biotyping, serotyping and phage typing might facilitate epidemiological investigations ${ }^{11}$ but would also complicate the methods and possibly require additional materials and time. Moreover, when conventional methods of typing Campylobacter spp. are used, a number of strains remain non-typable. Therefore, the value of PCR fingerprinting in delineating various characteristics was studied. The involvement of Campylobacter strains in epidemic spread, and whether new infectious episodes are due to persistence or re-infection, were investigated.

Characteristic DNA banding patterns, also known as DNA fingerprints, were obtained by the application of oligonucleotide PCR primers aimed at both dispersed repetitive DNA sequences and arbitrary DNA motifs. ${ }^{16,21}$ Although several other primers were studied, ERIC-1R, ERIC-2 and 1026 proved to be the best choice for typing $C$. jejuni, but could not be used successfully for $C$. upsaliensis. The study of the meningitis outbreak showed that it was possible to discriminate between outbreak and non-outbreak strains with a single PCR assay followed by a direct gel electrophoresis. Conventional typing results also showed that all outbreak strains were identical. The outbreak strains were of biotype 1, serotype LAU7/
PEN 18 and showed identical antibiotic susceptibility patterns, and protein and plasmid profiles. ${ }^{25}$ These results were in agreement with those obtained from PCR fingerprinting.

In the case of the $C$. upsaliensis outbreak, PCR fingerprinting provided additional information to that obtained with other typing methods. Although examination of the C. upsaliensis strains by plasmid analysis, antibiotic susceptibility testing, whole cell protein profile analysis, and phenotypic and biochemical testing ${ }^{26,27}$ (H. Goossens, unpublished results) indicated that the $C$. upsaliensis outbreak was caused by one strain, PCR fingerprinting, with more than one primer combination, showed that strains isolated from children at day-care centre A could be distinguished from strains isolated at the other day-care centres. These PCR results were corroborated by a study of this outbreak in which RFLP was used in addition to conventional typing methods (J. Van den Plas and H. Goossens, unpublished results). However, RFLP analysis revealed that only one of the 16 enzyme-probe combinations could discriminate strains from daycare centre A from day-care centres B, C and D (data not shown), and not all enzyme-probe combinations could be used.

These results suggest that two independent strains may have been responsible for the $C$. upsaliensis infections in day-care centre A and day-care centres B, $\mathrm{C}$ and $\mathrm{D}$, respectively. Another possibility is that during transmission of the infection from day-care centre $\mathrm{A}$ to the other day-care centres, or during culturing of the strains, some selection at the genetic level may have occurred. These potential genetic rearrangements during transmission or infection apparently have a more profound influence on the PCR fingerprint patterns generated with these primer combinations than on RFLP analysis.

Plasmid analysis showed an identical plasmid content for all these strains. Therefore, the differences observed with PCR fingerprinting and RFLP analysis cannot be explained by differences in plasmid DNA content. ${ }^{26}$ Furthermore, because serotyping for $C$. upsaliensis has not yet been developed, it is possible that a future serotyping system for $C$. upsaliensis might differentiate the outbreak-related isolates on the basis of antigenic differences. However, to investigate the level of genetic difference between strains from daycare centre A and day-care centres B, C and D, more PCR primers, capable of discriminating between different $C$. upsaliensis strains, should be used.

Although clear correlations were observed between PCR fingerprinting and serotyping data (fig. 1), ${ }^{17}$ typing of Campylobacter strains requires more detailed epidemiological study of larger groups of strains. One improvement would be the development of an automated system for post-amplification analysis and documentation. This would enable the standardisation of the technique, and would allow a comparison of patterns derived from different agarose gels. However, the applicability of this simple and rapid technique in 
epidemiological studies is clearly demonstrated by the results obtained in this study.

\section{References}

1. Penner JL. The genus Campylobacter: a decade of progress. Clin Microbiol Rev 1988; 1: 157-172.

2. Blaser MJ, Taylor DN, Feldman RA. Epidemiology of Campylobacter jejuni infections. Epidemiol Rev 1983; 5: 157-176.

3. Bolton FJ, Holt AV, Hutchinson DN. Campylobacter biotyping scheme of epidemiological value. J Clin Pathol 1984; 37: $677-681$.

4. Lior H. New, extended biotyping scheme for Campylobacter jejuni, Campylobacter coli and "Campylobacter laridis". $J$ Clin Microbiol 1984; 20: 636-640.

5. Skirrow MB, Benjamin J. Differentiation of enteropathogenic Campylobacters. J Clin Pathol 1980; 33: 1122.

6. Lior H, Woodward DL, Edgar JA, Caproche LJ, Gill P. Serotyping of Campylobacter jejuni by slide agglutination based on heat-labile antigenic factors. J Clin Microbiol 1982; 15: 761-768.

7. Penner JL, Hennesy JN, Congi RV. Serotyping of Campylobacter jejuni and Campylobacter coli on the basis of thermostable antigens. Eur J Clin Microbiol 1983; 2: 378-383.

8. Grajewski BA, Kusek JW, Gelfand HM. Development of a bacteriophage typing scheme for Campylobacter jejuni and Campylobacter coli. J Clin Microbiol 1985; 22: 13-18.

9. Lior H, Patel A. Improved toluidine blue-DNA agar for detection of DNA hydrolysis by Campylobacters. J Clin Microbiol 1987; 25: 2030-2031.

10. Salama SM, Bolton FJ, Hutchinson DN. Application of a new phage typing scheme to Campylobacters isolated during outbreaks. Epidemiol Infect 1990; 104: 405-411.

11. Khakhria R, Lior H. Extended phage-typing scheme for Campylobacter jejuni and Campylobacter coli. Epidemiol Infect 1992; 108: 403-414.

12. Lior H, Woodward D, Khakhria R. Characterization of Campylobacter jejuni outbreaks by 3 epidemiological typing markers. In: Kaijser B, Falsen E (eds) Campylobacter IV. Kungalu, Sweden, Goterna. 1988: 103-104.

13. Patton CM, Wachsmuth IK, Evins GM et al. Evaluation of 10 methods to distinguish epidemic-associated Campylobacter strains. J Clin Microbiol 1991; 29: 680-688.

14. Jayarao BM, Bassam BJ, Caetano-Anollés G, Gresshoff PM, Oliver SP. Subtyping of Streptococcus uberis by DNA amplification fingerprinting. $J$ Clin Microbiol 1992; 30: 1347-1350.

15. McMillin DE, Muldrow LL. Typing of toxic strains of Clostridium difficile using DNA fingerprints generated with arbitrary polymerase chain reaction primers. FEMS Microbiol Lett 1992; 92 : 5-10.

16. Van Belkum A, De Jonckheere J, Quint WGV. Genotyping Naegleria spp. and Naegleria fowleri isolates by interrepeat polymerase chain reaction. J Clin Microbiol 1992; 30: 2595-2598.

17. Mazurier S, Van de Giessen A, Heuvelman K, Wernars K.
We thank H. Lior, J. Penner and S. Lauwers for providing the reference serotype strains, $M$. Henkens for technical support and M. Canning for correcting language use and spelling.
RAPD analysis of Campylobacter isolates: fingerprinting without the need to purify DNA. Lett Appl Microbiol 1992; 14: $260-262$

18. Van de Giessen A, Mazurier SI, Jacobs-Reitsma W et al. Study on the epidemiology and control of Campylobacter jejuni in poultry broiler flocks. Appl Environ Microbiol 1992; 58: 1913-1917.

19. Giesendorf BAJ, Van Belkum A, Koeken A et al. Development of species-specific DNA probes for Campylobacter jejuni, Campylobacter coli, and Campylobacter lari by polymerase chain reaction fingerprinting. J Clin Microbiol 1993; 31: $1541-1546$.

20. De Bruijn FJ. Use of repetitive (repetitive extragenic palindromic and enterobacterial repetitive intergenic consensus) sequences and the polymerase chain reaction to fingerprint the genomes of Rhizobium meliloti isolates and other soil bacteria. Appl Environ Microbiol 1992; 58: $2180-2187$.

21. Versalovic J, Koeuth T, Lupski JR. Distribution of repetitive DNA sequences in eubacteria and application to fingerprinting of bacterial genomes. Nucleic Acids Res 1991; 19: 6823-6831.

22. Higgins CF, McLaren RS, Newbury SF. Repetitive extragenic palindromic sequences, mRNA stability and gene expression: evolution by gene conversion? A review. Gene 1988; 72: $3-14$.

23. Goossens H, Kremp L, Boury R et al. Nosocomial outbreak of Campylobacter jejuni meningitis in newborn infants. Lancet 1986; 2: 146-149.

24. Lauwers S, Vlaes L, Butzler JP. Campylobacter serotyping and epidemiology. Lancet 1981; 1: 158.

25. Goossens H, Van den Borre C, Vlaes L et al. Comparison of epidemiological markers for the investigation of Campylobacter outbreaks. In: Kaijser B, Falsen E (eds) Campylobacter IV. Kungala, Sweden, Goterna. 1988: 271-272.

26. Goossens H, Hanicq P, N'Jufom S et al. Outbreak of Campylobacter upsaliensis in four day-care centers in Brussels, 92nd Annual Meeting of the American Society for Microbiology. C-105. 1992: 438.

27. Goossens H, Pot B, Vlaes L et al. Characterization and description of "Campylobacter upsaliensis" isolated from human feces. J Clin Microbiol 1990; 28: 1039-1046.

28. Goossens H, Vlaes L, De Boeck M et al. Is "Campylobacter upsaliensis" an unrecognised cause of human diarrhoea? Lancet 1990; 335: 584-586.

29. Giesendorf BAJ, Quint WGV, Henkens MHC, Stegeman H, Huf FA, Niesters HG. Rapid and sensitive detection of Campylobacter spp. in chicken products using the polymerase chain reaction. Appl Environ Microbiol 1992; 58: 3804-3808.

30. Sambrook J, Fritsch EF, Maniatis T. Molecular cloning: A laboratory manual, 2nd edn. Cold Spring Harbor Laboratory, Cold Spring Harbor, NY 1989.

31. Van Belkum A, Bax R, Peerbooms, Goessens WHF, van Leeuwen N, Quint WGV. Comparison of phage typing and DNA fingerprinting by polymerase chain reaction for discrimination of methicillin-resistant Staphylococcus aureus strains. J Clin Microbiol 1993; 31: 798--803. 